\title{
Bio-Concentration of Some Heavy Metals and Oxidative Stress Enzymes in Oreochromis niloticus (Tilapia fish) from the Hadejia- Nguru wetlands, Jigawa State.
}

\author{
Musa I.M'. and Imam, T.S. ${ }^{2}$ \\ ${ }^{1}$ Department of Fisheries and Aquaculture, \\ Federal University Dutse, Jigawa State. \\ ${ }^{2}$ Department of Biological Sciences, \\ Bayero University Kano.
}

Email: musafud01@gmail.com.

\begin{abstract}
The Hadejia- Nguru wetland is a vast land of intensive agricultural and fishing activities. It receives waste water through discharges from agricultural, sewage and industrial sources. Five points marked as sites $A, B, C, D$ and $E$ were used for the study. The study aimed in evaluating levels of some heavy metals Cadmium(Cd), Chromium(Cr),Aluminum $(\mathrm{Al}), \operatorname{Lead}(\mathrm{Pb})$ and Mercury $(\mathrm{Hg})$ in O. niloticus and their effect in inducing oxidative stress in the fish. The tissue of interest were gills, muscle and liver. Results obtained revealed concentration of heavy metal in the sequence $\mathrm{Hg}>\mathrm{Cr}>\mathrm{Pb}>\mathrm{Al}>\mathrm{Cd}$ in the fish. The highest level of heavy metals contamination was recorded in fish from sample site $B$. There was significant difference $(P<0.05)$ in fish from site $B$ compared with sites $C, D$ and $E$. Mean concentration of $\mathrm{Hg}$ recorded in the gills ranged from $249.75 \mathrm{mg} / \mathrm{kg}$ in site B to $128.50 \mathrm{mg} / \mathrm{kg}$ in site A, $118.75 \mathrm{mg} / \mathrm{kg}$ in site $D, 77.25 \mathrm{mg} / \mathrm{kg}$ in site $C$ and $62.0 \mathrm{mg} / \mathrm{kg}$ in site E. Oxidative stress markers such as superoxide dismutase, catalase, lipid peroxidation and reduced glutathione were significantly higher in the fish tissue indicating a stressful condition in the fish. Anthropogenic activities contributed to the high level of metals found in the wetland and this in turn is reflected in the oxidative stress in fish.
\end{abstract}

Keywords: Cichlid fish, Oxidative stress, Pollutants, Toxicity, Wetlands.

\section{INTRODUCTION}

Fish are largely being used for the assessment of the quality of aquatic environment and as such can serve as bio indicators of environmental pollution (Dautremepuits, 2004). In their natural environment they interact with available amount of pollution either from heavy metals or pesticides. These pollutants when accumulated in the tissues of fish may catalyze reactions that brings about reactive oxygen species (ROS) Farombi et al, 2007. This ROS is formed through two mechanisms which includes the formation of reactive oxygen species through redox cycling brought about as a result of the interactions of Redox active metals while metals without redox potential impair antioxidant defences, especially that of thiolcontaining antioxidants and enzymes (Sevcikova et al,2011, Akinwade et al., 2016) When the levels of ROS is raised it leads to oxidative damage including lipid peroxidation, protein and DNA oxidation and enzyme inactivation. Oxidative stress cannot be avoided in aerobic life, it results from imbalance between the production of ROS and antioxidant defensives in living organism (Nishida,2011). Elevated production of ROS can be readily induced by pesticides, 
transitional metal ions and petroleum pollutants (Lushchak, 2011). Elevated production of ROS causes oxidation of proteins and lipids, change/alterations in gene expression and changes in cell redox redox status (Sevcikova et al, 2011). Superoxide dismutase (SOD), Catalase (CAT), Glutathione reductase (GSH) and Glutathione - $\mathrm{s}$ - transferase (GST) are the main antioxidant enzymes and important indicators of oxidative stress. When fish is stressed oxidative stress enzymes are readily released becoming inducible and indicating their readiness to adapt to stressful conditions (Nwani et al., 2015). The Hadejia-Nguru wetland $(\mathrm{HNW})$ is a vastland of fisheries and Agriculture known for its immense productivity, it covers both Jigawa and Yobe states of Nigeria and extends to the Chad basin.Activities which includes mining, excavation and chemical applications have made the wetlands prune to pollutants and toxic substances, studies carried out on the soil and water of the wetlands by Sabo et al.,(2016), Egwu et al.,(2018) revealed some level of heavy metal contamination in soil and water but this study seeks to determine levels of heavy metals in O. niloticus. Therefore,this study is aimed at accessing the level of metallic pollution in the HNW and to evaluate the oxidative stress response in the fish.

\section{MATERIALS AND METHODS}

\section{Study Area}

The Hadejia - Nguru Wetlands (HNW) lies between latitudes $12^{\circ} 10 \mathrm{~N}$ and $13^{\circ} \mathrm{N}$ and longitudes $10^{\circ} 15 \mathrm{E}$ and $11^{\circ} 30 \mathrm{E}$. The HNW lies within the semi-arid region of Nigeria. The wetland has an area of about $3,500 \mathrm{~km}^{2}$. The topography of the area is mostly low lying flat surfaces on the north eastern side and limited local relief in the southern and western parts. Rainfall pattern in the Nguru- Hadejia wetland (NHW) has not been stable over the years, but in most cases starts from June and falls through September. Vegetation is mainly Sudan Savanna, with transitional northern Guinea Savanna and Sahel Savanna in the Southern and Northern limits respectively, Abubakar et al (2015)

Site A is Hadejia barrage dam (Kalgwai)

Site B: Kirikasanma

Site C: Maikintari

Site D: Nguru lake

Site E: Dagona 


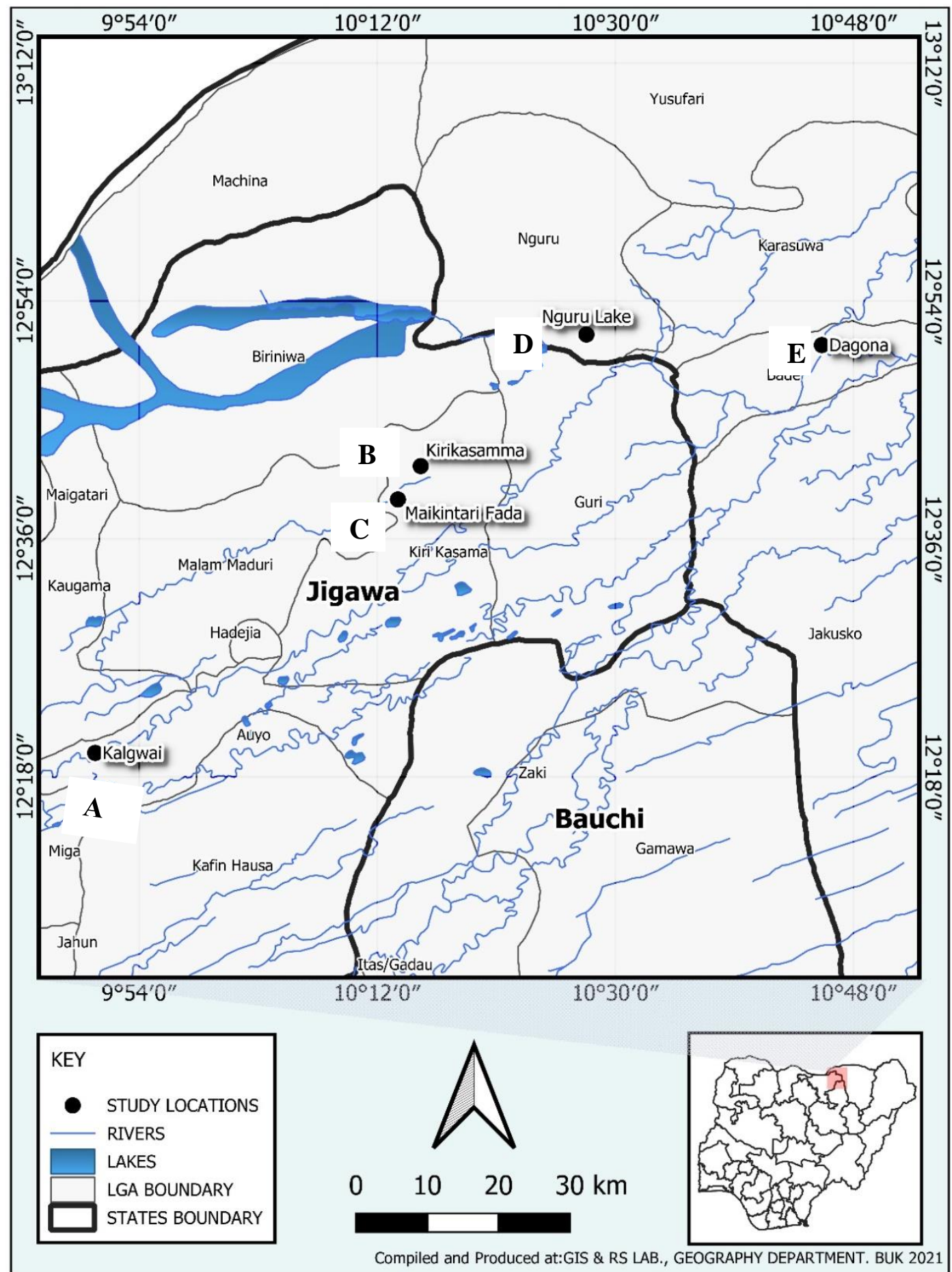

Figure 1: Map of the Hadejia-Nguru Wetland showing the five sampling sites.

Fish Sampling and Analysis: Oreochromis niloticus, were caught from the five sampling sites through the services of a hired fisherman. Samples were collected bi-monthly during the entire period of study. A total of 139 fish was used for the sampling. The Fish samples were gotten very early in the morning by 6a.m. and transported in ice cold containers to the Department of Fisheries and Aquaculture Federal University Dutse, laboratory for dissection and analysis. While the control fish was gotten from Rumbun kifi fish farm located at 
Modobbi road, Dutse, Jigawa state. From enquiries and observation it was gathered that the farm is free from pollution coming from any industry or facility that could affect the biochemical responses of the control fish.

The fishes were dissected and the gills, liver and muscles were removed then preserved in a refrigerator at a temperature of $-4^{0} \mathrm{C}$ for further experimentation.

\section{Analysis of Water sample}

Water samples were collected between 7-8:00am. The physicochemical parameters such as water temperature, turbidity, $\mathrm{pH}$, electrical conductivity, TDS, dissolved oxygen were analyzed according to the method of APHA, (1990). The water temperature was measured with a mercury in bulb thermometer, which was dipped into the water and temperature was read off, the turbidity was measured using a secchi disc by lowering into the water and then measuring the depth at which transparency was seen. The $\mathrm{pH}$, Dissolved oxygen, conductivity and total dissolved solid was measured with a compact D.O. meter Hannan model HI9146, Woonsocket, RI USA.

\section{Heavy Metal Analysis}

Analysis was carried by the wet method as used by Tyokumbur, (2016). Dissected muscles, gills and liver were removed and oven dried at a temperature of $105^{\circ} \mathrm{C}$ until a constant weight was achieved, the dried samples were turned in to powdery form using a porcelain mortar prior to digestion. To digest the samples the powdered muscles, gills and liver were homogenized and subjected to concentrated nitric acid and hydrogen peroxide $(1: 1) \mathrm{v} / \mathrm{v}$ of the powdered sample was placed into a $250 \mathrm{ml}$ round bottom flask and $10 \mathrm{ml}$ each of $\mathrm{HNO}_{3}(65 \%)$ and $\mathrm{H}_{2} \mathrm{O}_{2}(30 \%)$ were added and the content of the flask was allowed to undergo reactions. The content of the flask was heated on a heating mantle to a temperature of $130^{\circ} \mathrm{C}$ dissolution inside a fume hood to reduce the volume to $3 \mathrm{ml}-4 \mathrm{ml}$, the digested sample was allowed to cool and filtered into a conical flask, the filtered sample was transferred to a $50 \mathrm{ml}$ volumetric flask. The concentration of $\mathrm{Cd}, \mathrm{Al}, \mathrm{Cr}, \mathrm{Pb}$ and $\mathrm{Cd}$ was determined using the Atomic Absorption spectrophotometer (Buck scientific model 230) at the soil science Department of Ahmadu Bello University, Zaria. Same was done for water and sediments.

\section{Measurement of Oxidative Stress Markers}

The liver samples was assessed for oxidative stress markers- superoxide dismutase (SOD), catalase(CAT), glutathione(GSH)and the lipid peroxidation (Malondialdehyde MDA). These was determined by adopting the methods of analysis as described by Achuba et al.,(2014).

\section{Preparation of extract for the determination of lipid peroxidation (MDA)}

Of the isolated gills, liver and muscles, $0.5 \mathrm{~g}$ were separated and homogenized with $10 \mathrm{ml}$ of ice-cold $0.05 \mathrm{M}$ phosphate butter $\mathrm{pH} 7.0$ containing $1 \%(\mathrm{w} / \mathrm{v})$ Triton $\mathrm{X}-100$, excess butylated hydroxyl toluene (BHT) and a few crystals of protease inhibitor, phenylmethylsulfonyl fluoride using an MSE blender immersed in ice. Triton X-100 solubilizes membrane-enclosed organelles while BHT prevents in vitro oxidation of lipid during homogenization. The extract was centrifuged at $7000 \mathrm{~g}$ for $20 \mathrm{~min}$ (40C). The supernatant (S1) was used for the determination of lipid peroxidation by the method of Hunter et al.,(1963) as modified by Gutteridge and Wilkins (1982).

\section{Extraction and Assay of Catalase (CAT)}

Catalase activity was determined according to Beers and Sizer (1952) by measuring the decrease in the $\mathrm{H}_{2} \mathrm{O}_{2}$ concentration, at an absorbance of $240 \mathrm{~nm}$. An extinction coefficient for $\mathrm{H}_{2} \mathrm{O}_{2}$ of $40 \mathrm{M}-1 \mathrm{~cm}-1$ (Abel, 1974) was used in the calculation. 


\section{Extraction and Assay of Superoxide Dismutase (SOD)}

The obtained supernatant was used for the assay of superoxide dismutase (SOD) activity, which was based on its ability to inhibit the oxidation of epinephrine by superoxide anion (Aksnes and Njaa, 1981). The enzyme activities were assayed with an SP 1800 UV/VIS Spectrophotometer.

\section{Sample preparation of Glutathione (GSH)}

Tissue sample was prepared by washing with PBS twice, $0.1 \mathrm{~g}$ of the sample was added into homogenizer, $1 \mathrm{~mL}$ reagent was added (the proportion of tissue and reagents are kept constant) and this was fully grinded on ice (using liquid nitrogen gave a better grinding effect) centrifuge was done at $8000 \mathrm{x}$ g for 10 minutes at $4{ }^{\circ} \mathrm{C}$ the supernatant was placed at $4{ }^{\circ} \mathrm{C}$. Spectrophotometer was then preheated for 30 minutes and adjustment was made to a wave length of $412 \mathrm{~nm}$ with distilled water.

\section{Statistical Analysis}

Data generated were analyzed using statistical package for social sciences (SPSS) version 25. All the results were expressed as means \pm SD and the data were analyzed using Analysis of variance (ANOVA). Significant difference between the polluted sites and control were determined at 5\% $(\mathrm{P}<0.05)$ confidence level using Duncan multiple test range.

\section{Results}

Mean Physiochemical parameters result is presented in Table 1; mean range of water temperature was between $25.37{ }^{\circ} \mathrm{C}$ and $27.23^{\circ} \mathrm{C}$ with the highest value seen in site $\mathrm{E}$, there was no significant difference $(\mathrm{P}<0.05)$ in recorded temperature in all the sampling sites. Dissolved oxygen values ranged from $5.34 \mathrm{mgl}^{-1}$ in site $\mathrm{A}$ to $6.08 \mathrm{mgl}^{-1}$ in site $\mathrm{B}$. the values for total dissolved solid showed a slight variation in site E, while sites B, C, A and D showed high values of $405 \mathrm{mgl}^{-1}, 352.42 \mathrm{mgl}^{-1}, 320.10 \mathrm{mgl}^{-1}$ and $308.79 \mathrm{mgl}^{-1}$ respectively. Electrical conductivity of water samples gave values of $226.89 \mu \mathrm{S} / \mathrm{cm}$ in site $\mathrm{C}$ to $400.10 \mu \mathrm{S} / \mathrm{cm}$ in site $\mathrm{B}$, there was significant difference $(\mathrm{P}>0.05)$ between site $\mathrm{B}$ and the other sites in terms of electrical conductivity. Mean values of turbidity ranged between $25.50 \mathrm{NTU}$ in site D and 28.76NTU in site C. $\mathrm{pH}$ values were between the range of 7.23-7.48 and there was no significant difference $(\mathrm{P}<0.05)$ among the sites.

\section{Heavy metals}

Water sample results presented in figure 2 revealed a concentration value of $0.40 \mathrm{mgl}^{-1}$ for $\mathrm{Al}$ and a highest value in site $\mathrm{E}$. The highest concentration of $\mathrm{Cd}$ was recorded in site $\mathrm{A}$ with a value of $0.008 \mathrm{mgl}^{-1}$ followed by $0.007 \mathrm{mgl}^{-1}$ in site $\mathrm{B}$. Cr in water sample was highest in site E with a value of $1.004 \mathrm{mg}^{-1} \mathrm{~Pb}$ had a highest value of $0.058 \mathrm{mgl}^{-1}$ in site E followed by $0.049 \mathrm{mg}^{-}$ 1 in site $\mathrm{D}$ respectively.

Results presented in figure 3 showed the heavy metal deposition in the sediments of the $\mathrm{HNW}$, the variation in concentration showed that site A had a high level of $\mathrm{Al}$ as $47.1 \mathrm{mg} / \mathrm{Kg}$, $2.0 \mathrm{mg} / \mathrm{Kg}$ of Cd, $45.0 \mathrm{mg} / \mathrm{Kg}$ of Cr, $116.25 \mathrm{mg} / \mathrm{Kg}$ of $\mathrm{Pb}$ and $22.8 \mathrm{mg} / \mathrm{Kg}$ of $\mathrm{Hg}$. Site B had the following concentration level of the studied metals, Al was $8.19 \mathrm{mg} / \mathrm{Kg}$, Cd had 1.75 $\mathrm{mg} / \mathrm{Kg}$ in concentration, $\mathrm{Cr}$ had $227.3 \mathrm{mg} / \mathrm{Kg}, \mathrm{Pb} 117.3 \mathrm{mg} / \mathrm{Kg}$ and $\mathrm{Hg} 95.8 \mathrm{mg} / \mathrm{Kg}$. Concentration of metals in site $\mathrm{C}$ showed that $\mathrm{Al}$ had a concentration of $20.71 \mathrm{mg} / \mathrm{Kg}$, Cd 1.7 $\mathrm{mg} / \mathrm{Kg}, \mathrm{Cr} 220.0 \mathrm{mg} / \mathrm{Kg}, \mathrm{Pb} 118.75 \mathrm{mg} / \mathrm{Kg}$ and $\mathrm{Hg} 83.0 \mathrm{mg} / \mathrm{Kg}$. Site D showed the following concentration in metal level in the sediments $\mathrm{Al}$ was $17.31 \mathrm{mg} / \mathrm{Kg}, \mathrm{Cd} 3.0 \mathrm{mg} / \mathrm{Kg}, \mathrm{Cr} 150.50$ $\mathrm{mg} / \mathrm{Kg}$, $\mathrm{Pb} 132.0 \mathrm{mg} / \mathrm{Kg}$ and $\mathrm{Hg}$ was $115.8 \mathrm{mg} / \mathrm{Kg}$. 
Figure 4, illustrates the heavy metals concentration in the gills, liver and muscles of $O$. niloticus in site A. The concentration of heavy metals in gills of O. niloticus showed that mercury was the highest with a mean concentration level of $128.5 \mathrm{mg} / \mathrm{Kg}$. Lead had a mean level of 14.0 $\mathrm{mg} / \mathrm{Kg}$ while $\mathrm{Cd}$ and $\mathrm{Al}$ had $3.5 \mathrm{mg} / \mathrm{Kg}$ and $2.05 \mathrm{mg} / \mathrm{Kg}$. Liver of O. niloticus revealed concentration levels of heavy metals which showed $\mathrm{Hg}>\mathrm{Cr}>\mathrm{Pb}>\mathrm{Cd}>\mathrm{Al}$ in the order of concentration. The muscles of $\mathrm{O}$. niloticus showed results in which $\mathrm{Hg}>\mathrm{Cr}>\mathrm{Pb}>\mathrm{Al}>\mathrm{Cd}$. Heavy metals accumulation in gills, liver and muscles of the fish in site A revealed that $\mathrm{Hg}$ and $\mathrm{Cr}$ were the heavy metals that had high concentration level. The concentration of all the metals followed the order $\mathrm{Hg}>\mathrm{Cr}>\mathrm{Pb}>\mathrm{Cd}>\mathrm{Al}$.

Concentration of heavy metals in site B is presented in figure 4. Concentration of metals in $O$. niloticus showed that the gills had a high concentration of $\mathrm{Cr} 210.0 \mathrm{mg} / \mathrm{Kg}$. Liver samples revealed concentration of $249.75 \mathrm{mg} / \mathrm{Kg}$ of $\mathrm{Hg}, 111.25 \mathrm{mg} / \mathrm{Kg}$ of $\mathrm{Cr}, 6.59 \mathrm{mg} / \mathrm{Kg}$ of Al, 3.25 $\mathrm{mg} / \mathrm{Kg}$ of $\mathrm{Cd}$ and $3.0 \mathrm{mg} / \mathrm{Kg}$ of $\mathrm{Pb}$. There is significantly difference $(\mathrm{P}<0.05)$ in the concentration of $\mathrm{Hg}$ in comparison with the other heavy metals present in site $\mathrm{B}$.

Metal concentration in $\mathrm{O}$. niloticus from site $\mathrm{C}$ is presented in figure 4 . Concentration of heavy metals in the gills, liver and muscle in O. niloticus was $169.0 \mathrm{mg} / \mathrm{Kg}$ of $\mathrm{Cr}, 77.3 \mathrm{mg} / \mathrm{Kg}$ of Hg , $3.75 \mathrm{mg} / \mathrm{Kg}$ of $\mathrm{Cd}, 3.5 \mathrm{mg} / \mathrm{Kg}$ of $\mathrm{Pb}$ and $2.94 \mathrm{mg} / \mathrm{Kg}$ of Al. There was significant difference $(\mathrm{P}<0.05)$ in the concentration of $\mathrm{Cr}$ with other metals as seen in the gills. Concentration of heavy metals in site $\mathrm{D}$ is presented in figure 4 . Concentration of the studied heavy metals in O. niloticus revealed that the gills had a high concentration of $\mathrm{Hg}$ with a value of $118.7 \mathrm{mg} / \mathrm{kg}$.

Concentration of the heavy metals in O. niloticus from site $\mathrm{E}$ is presented in figure $4, \mathrm{Hg}$ in gills, liver and muscles showed a concentration level of $62.0 \mathrm{mg} / \mathrm{Kg}, 120 \mathrm{mg} / \mathrm{Kg}$, and $128.0 \mathrm{mg} / \mathrm{Kg}$, while that of $\mathrm{Cr}$ was $177.5 \mathrm{mg} / \mathrm{Kg}, 28.5 \mathrm{mg} / \mathrm{Kg}$ and $33.75 \mathrm{mg} / \mathrm{Kg}$. Concentration of heavy metals in the control fish is presented in figure 4, which showed a relatively lower concentration in all the sampled heavy metals.

The result revealed that site $\mathrm{B}$ had the highest level of heavy metal contamination followed by site $A$, there was significant difference $(\mathrm{P}<0.005)$ in contamination level in site $\mathrm{B}$ with sites $\mathrm{C}, \mathrm{D}$ and $\mathrm{E}$.

\section{Oxidative stress Biomarkers}

Oxidative stress biomarkers were studied in the gills, liver and muscles of O. niloticus from the HNW. The oxidative stress biomarkers were superoxide dismutase, gluthathione, catalase and lipid peroxidation. Table 2 showed the levels SOD in organs of the sampled fish specie. The result showed that in $O$. niloticus the concentration of superoxide dismutase in the gills were highest in site $C$, while concentration in the liver was $25.37 \mathrm{uml}^{-1}$ also from site $C$, the SOD concentration of the muscle was 16.40 uml-1. $^{-1}$

Table 3 shows the levels of GSH activities in organs of O. niloticus.. The GSH levels in the various organs of $O$. niloticus was seen to be significantly high $(\mathrm{P}<0.05)$ in the liver, gills and muscle of the fish. Fish samples from site B had the highest GSH levels in the gills while, the liver of site $\mathrm{E}$ had the value of 97.13 .

The levels of CAT formation in O. niloticus is shown in Table 4. There are more elevated levels of CAT in the gills of $O$. niloticus, there was markedly increase as seen in the gills $(\mathrm{P}<0.05)$. The gills with the highest level of CAT are from site E, followed by site D with values of 10.17 $\mathrm{uml}^{-1}$ and $6.78 \mathrm{uml}^{-1}$. The CAT level in the liver samples of $O$. niloticus is seen to be highest in site $B$ with a value of $14.92 \mathrm{uml}^{-1}$ and is significantly different $(\mathrm{P}<0.05)$ in the gills of fish. 
The levels of MDA formation in O. niloticus is shown in Table 5. Site A had a MDA value of $4.72 \mathrm{nmol}$, while fish from site $B$ had a value of $4.73 \mathrm{nmol}$, site $C$ fish had $7.71 \mathrm{nmol}$, while D was $9.03 \mathrm{nmol}$ and $\mathrm{E}$ was $5.85 \mathrm{nmol}$. The highest value was seen in site $\mathrm{D}$ with a value of 9.03 nmol. The MDA formation in the liver was highest in site $D$ with a value of $8.97 \mathrm{nmol}$ and there was no significant difference $(\mathrm{P}>0.05)$ between site $\mathrm{A}, \mathrm{B}$ and $\mathrm{C}$. Levels of MDA seen in the muscles had a level formation of $9.06 \mathrm{nmol}$, this value is of no significant difference $(\mathrm{P}>0.05)$ between sites A, B, C, D and E.

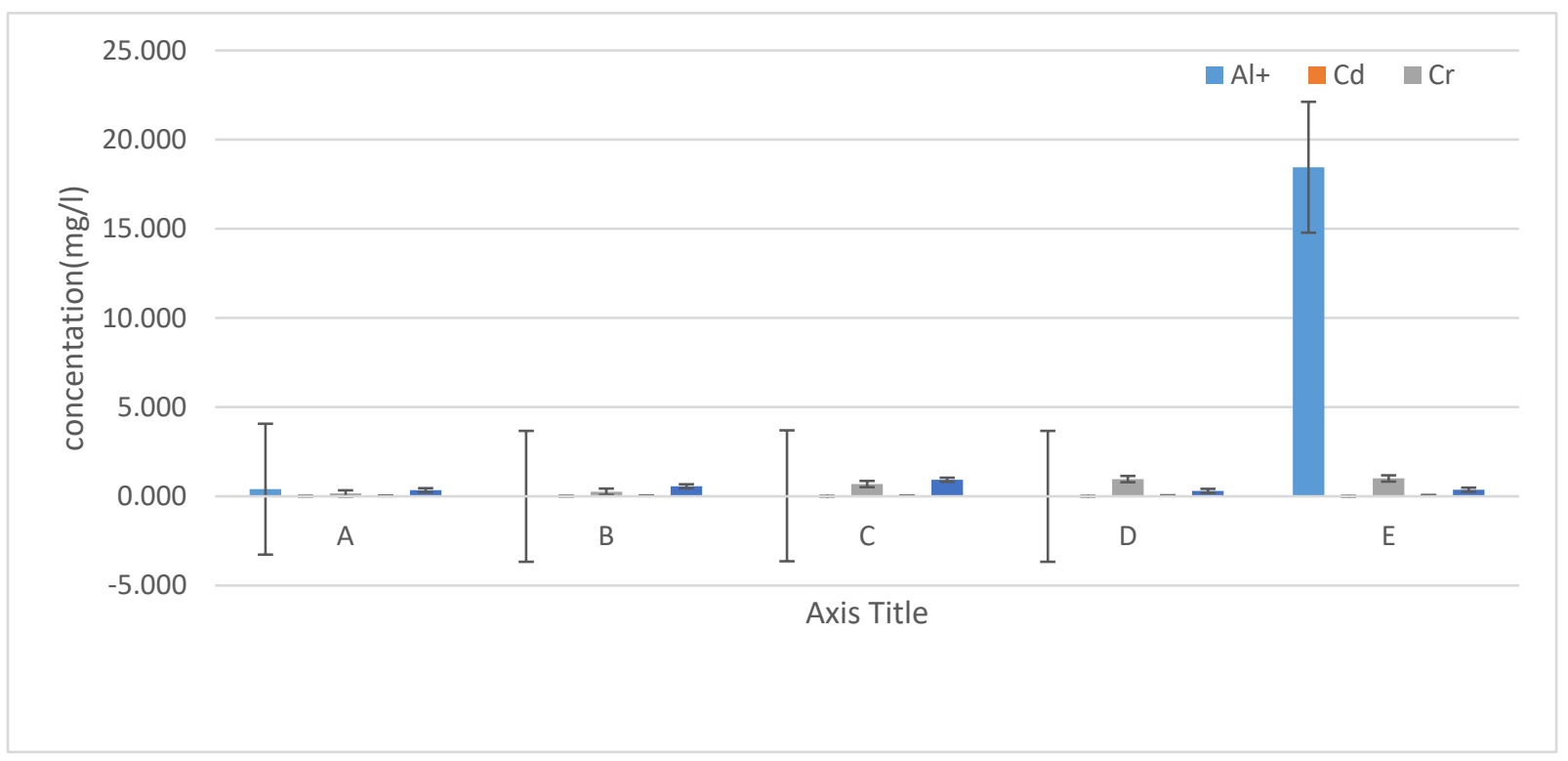

Figure 2: Heavy metal concentration in water at the HNW

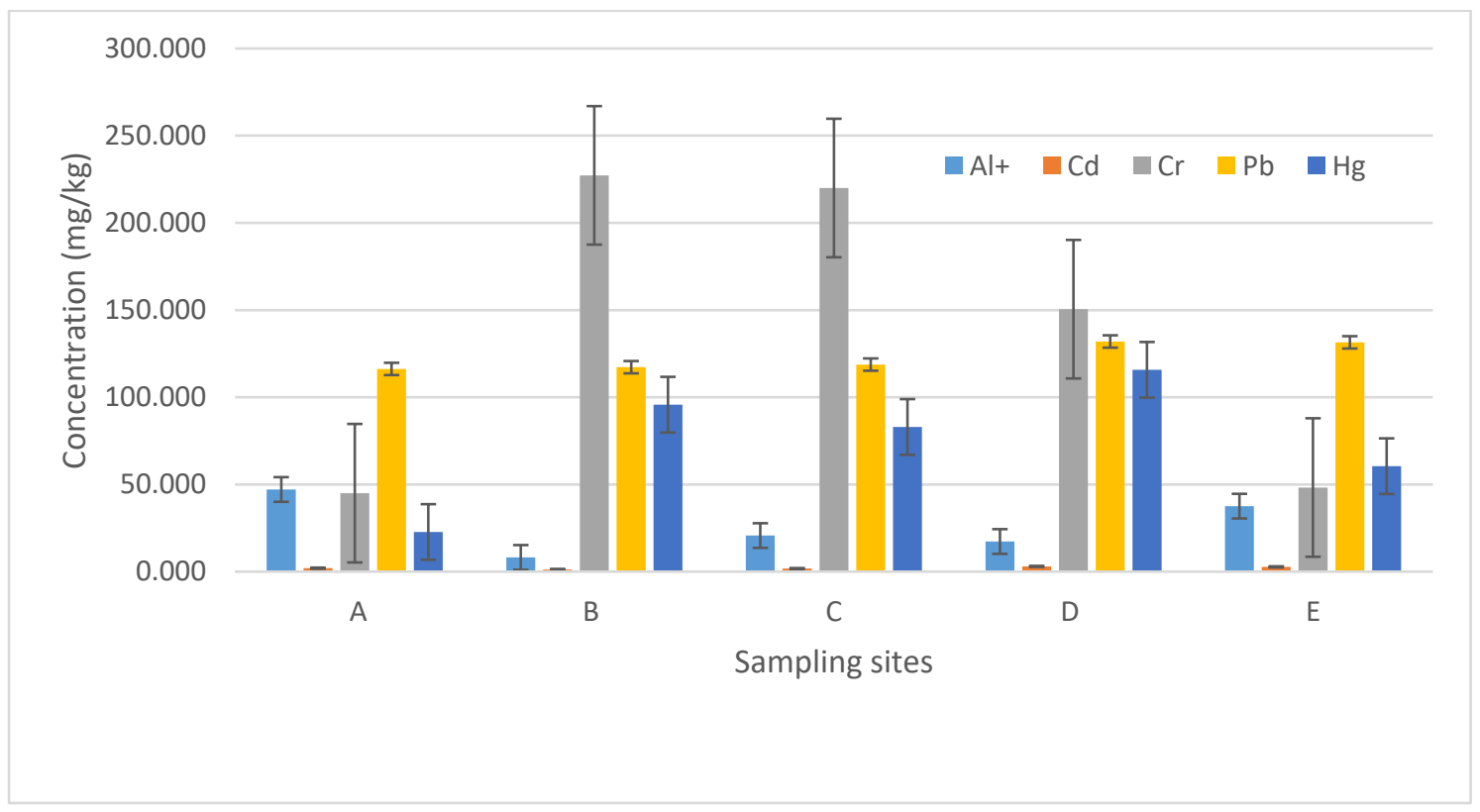

Figure3: Heavy metal concentration in sediments of $\mathrm{HNW}$ 


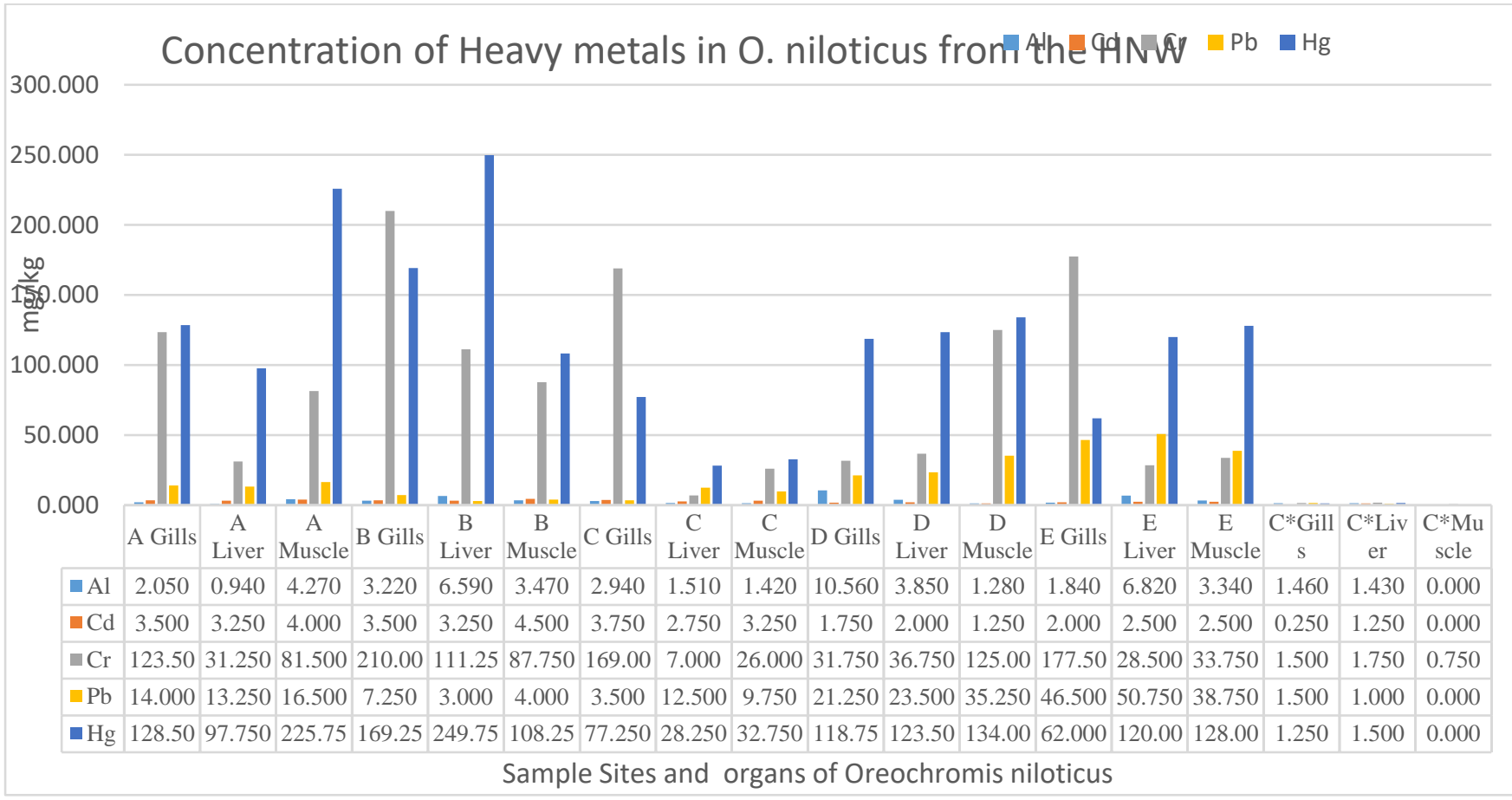

Figure 4: Heavy metals concentration in organs of O. niloticus from the Hadejia-Nguru wetlands

$\mathrm{C}^{*}=$ Control

Table 1: Mean physicochemical values obtained from the Hadejia-Nguru wetlands

\begin{tabular}{|c|c|c|c|c|c|c|}
\hline s & $\mathbf{A}$ & B & $\mathrm{C}$ & $\mathrm{D}$ & $\mathrm{E}$ & Standard limits \\
\hline $\begin{array}{l}\text { Water } \\
\text { temperature }\left({ }^{\circ} \mathrm{C}\right)\end{array}$ & $25.37 \pm 0.31^{a}$ & $26.12 \pm 0.53^{a}$ & $26.90 \pm 0.54^{\mathrm{a}}$ & $27.20 \pm 0.05^{\mathrm{a}}$ & $27.23 \pm 0.02^{\mathrm{a}}$ & $<40^{\circ} \mathrm{C}^{*}$ \\
\hline D.O. $(\mathrm{mg} / \mathrm{l})$ & $5.34 \pm 0.57 a$ & $6.08 \pm 0.51^{\mathrm{a}}$ & $6.02 \pm 0.08^{a}$ & $5.50 \pm 0.01^{\mathrm{a}}$ & $5.55 \pm 0.05^{\mathrm{a}}$ & $5.0-9.0 \mathrm{mg} / 1^{* *}$ \\
\hline TDS (mg/l) & $320.10 \pm 0.3 b$ & $405.69 \pm 0.14 \mathrm{~d}$ & $352.42 \pm 0.33 c$ & $308.79 \pm 0.49 b$ & $296.36 \pm 0.17 a$ & $<600 \mathrm{mg} / \mathrm{l}^{*}$ \\
\hline $\begin{array}{l}\text { Electrical } \\
\text { conductivity }(\mu \mathrm{S} / \mathrm{c} \\
\mathrm{m})\end{array}$ & $267.41 \pm 0.8^{b}$ & $400.10 \pm 0.82^{\mathrm{d}}$ & $352.23 \pm 0.59 c$ & $226.89 \pm 0.99 a$ & $270.40 \pm 0.41^{b}$ & $<1000 \mu \mathrm{s} / \mathrm{cm}^{* *}$ \\
\hline Turbidity(NTU) & $28.03 \pm 0.48^{b}$ & $28.67 \pm 0.39 b$ & $28.76 \pm 0.33^{b}$ & $25.50 \pm 0.49 a$ & $24.80 \pm 0.52^{a}$ & $<25 \mathrm{NTU}^{* * *}$ \\
\hline $\mathrm{PH}$ & $7.23 \pm 0.029 \mathrm{a}$ & $7.47 \pm 0.39 \mathrm{a}$ & $7.48 \pm 0.40^{\mathrm{a}}$ & $7.42 \pm 0.01^{\mathrm{a}}$ & $7.40 \pm 0.00^{\mathrm{a}}$ & $6.0-9.0^{*}$ \\
\hline
\end{tabular}

*Federal Environmental Protection Agency (1991), **Federal Ministry of Environment (2001), ***World Health Organization (1999)

Table 2: Levels of SOD in organs of Oreochromis niloticus from the HNW (unit of measurement is $\mathrm{U} / \mathrm{ml}$ )

O. niloticus

Organ/Tissue

Control

$1.43 \pm 0.30$

$3.41 \pm 0.21^{\mathrm{b}}$

$15.11 \pm 0.11^{\mathrm{c}}$

$12.70 \pm 2.14^{\mathrm{c}}$

$0.82 \pm 0.02^{\mathrm{a}}$

$2.50 \pm 0.20^{\mathrm{b}}$

$0.35 \pm 0.03^{a}$

$3.73 \pm 2.70^{\mathrm{b}}$

$16.40 \pm 4.20^{c}$

Muscle
SITE

B

C

D

E

$0.35 \pm 0.20$ a

$3.60 \pm 0.10^{\mathrm{b}}$

Values are means \pm SD of determination for a single fish specie from five (5) points in the HNW- means with different superscript letters in the same row are significantly different at $\mathrm{P}<0.005$.

$\mathrm{ND}=$ not detected 
Table 3: Levels of GSH in organs of Oreochromis niloticus from the HNW (unit of measurement is $\mu \mathrm{g} / \mathrm{ml}$ )

\begin{tabular}{|c|c|c|c|c|c|c|}
\hline \multirow{2}{*}{$\begin{array}{l}\text { O. niloticus } \\
\text { Organ/Tissue }\end{array}$} & \multicolumn{5}{|c|}{ SITE } & \multirow[b]{2}{*}{$\mathrm{E}$} \\
\hline & Control & $\mathrm{A}$ & $\mathrm{B}$ & $\mathrm{C}$ & $\mathrm{D}$ & \\
\hline Gills & $7.30 \pm 1.05^{a}$ & $151.06 \pm 0.99 c$ & $388.08 \pm 2.07 \mathrm{e}$ & $66.94 \pm 6.12^{b}$ & $104.32 \pm 4.21^{c}$ & $121.12 \pm 1.04^{\mathrm{d}}$ \\
\hline Liver & $0.81 \pm 1.01^{\mathrm{a}}$ & ND & $18.21 \pm 8.11^{b}$ & $29.48 \pm 0.24^{c}$ & $63.80 \pm 3.10^{\mathrm{d}}$ & $97.13 \pm 7.12^{\mathrm{d}}$ \\
\hline Muscle & $1.61 \pm 1.50^{a}$ & $104.32 \pm 4.22^{b}$ & $253.15 \pm 3.05^{\mathrm{d}}$ & $213.44 \pm 13^{c}$ & $153.14 \pm 4.04^{b}$ & $322.87 \pm 21.7 \mathrm{e}$ \\
\hline
\end{tabular}

Values are means \pm SD of determination for a single fish specie from five (5) points in the HNW- means with different superscript letters in the same row are significantly different at $\mathrm{P}<0.005$.

$\mathrm{ND}=$ not detected

Table 4: Levels of Catalase in organs of Oreochromis niloticus from the HNW (unit of measurement is $\mathrm{U} / \mathrm{ml}$ )

\begin{tabular}{llccccc} 
O. niloticus & \multicolumn{5}{c}{ SITE } \\
Organ/Tissue & Control & A & B & C & D & E \\
\hline Gills & ND & $0.68 \pm 0.00^{\mathrm{a}}$ & $\mathrm{ND}$ & $3.39 \pm 1.00^{\mathrm{b}}$ & $6.78 \pm 0.81^{\mathrm{c}}$ & $10.17 \pm 0.20^{\mathrm{d}}$ \\
Liver & $\mathrm{ND}$ & $0.86 \pm 0.38^{\mathrm{a}}$ & $14.92 \pm 2.81^{\mathrm{b}}$ & $\mathrm{ND}$ & $0.65 \pm 0.04^{\mathrm{a}}$ & $0.68 \pm 0.01^{\mathrm{a}}$ \\
Muscle & $0.68 \pm 0.01^{\mathrm{a}}$ & $4.75 \pm 1.23^{\mathrm{b}}$ & $0.68 \pm 0.01^{\mathrm{a}}$ & $2.03 \pm 0.05^{\mathrm{b}}$ & $\mathrm{ND}$ & $0.68 \pm 0.01^{\mathrm{a}}$
\end{tabular}

Values are means \pm SD of determination for a single fish specie from five (5) points in the HNW- means with different superscript letters in the same row are significantly different at $\mathrm{P}<0.005$.

$\mathrm{ND}=$ not detected

Table 5: Levels of Malondialdehyde in organs of Oreochromis niloticus from the HNW (unit of measurement is $\mathrm{n} / \mathrm{mol}$ )

O. niloticus

Organ/Tissue

Gills

Liver

Muscle

$0.61 \pm 0.37$

ND

Control

A

$4.72 \pm 1.60^{\mathrm{b}}$

$6.30 \pm 0.30$ c

$1.06 \pm 0.03^{a}$

$1.68 \pm 0.43^{a}$

SITE

Values are means \pm SD of determination for a single fish specie from five (5) points in the HNW- means with different superscript letters in the same row are significantly different at $\mathrm{P}<0.005$.

$\mathrm{ND}=$ not detected 


\section{DISCUSSION}

Results revealed that the wetland is contaminated with the studied heavy metals in higher proportion exceeding the maximum recommended limits in aquatic foods, concentration of heavy metals in the body of fish was higher than the concentration in the water body, this is as a result of the ability of fish to bio accumulate metals above the concentration in water. Nsofor et al., (2014).This agrees with the work of Adaka et al., (2017) stating that heavy metals in the body organs of Citharus citharus, T. zillii and Heterotis niloticus from Oguta lake gave a higher concentration than water concentration. Heavy metal contamination in site A resulted to a massive accumulation in fish tissue, The high level of $\mathrm{Hg}$ and $\mathrm{Cr}$ can be attributed to anthropogenic sources, even though unpolluted water contains trace amounts of $\mathrm{Hg}$ which do not exceed $0.1 \mu \mathrm{g} / \mathrm{l}$, the main source of $\mathrm{Hg}$ in environment is the fungicides, especially in the organic compounds of mercury. The amount of $\mathrm{Hg}$ in the muscles of O. niloticus was higher than the other organs put together, this agrees with the findings of Golovanova, (2006) that visceral distribution of $\mathrm{Hg}$ in organs and tissues often shows the following order Muscles $>$ liver $>$ intestine $>$ spleen $>$ brain $>$ gonads this is due to the high content in muscles of functional proteins ( $-\mathrm{SH},-\mathrm{NH}_{2},-\mathrm{COOH},-\mathrm{OH}$ ) having high affinity to $\mathrm{Hg}$. The presence of $\mathrm{Hg}$ even at low concentrations reduces the viability of spermatozoa in fish, reduces production of eggs and affects the survival rate of developing eggs and fry. Concentration of $\mathrm{Cr}$ was high in sample site A beyond the recommended acceptable limit in food. The $\mathrm{Cr}$ gains entrance in to the aquatic ecosystem through effluents discharged from mining, dyeing, leather tanneries, textiles. The $\mathrm{Cr}$ level observed in the study showed a higher concentration and Fish takes in $\mathrm{Cr}$ by ingestion or by uptake through the gills, and accumulates morphological alterations. $\mathrm{Pb}$ has been classified as one of the most toxic metals, and a high mean concentration was found in the muscles of $O$. niloticus $\mathrm{Pb}$ is naturally available substance with its concentration increased by anthropogenic sources which could be base metal mining, $\mathrm{Pb}$ based paints and gasoline. Lead in water may come from industrial and smelter discharges, $\mathrm{Pb}$ containing pesticides, street runoff and municipal waste water. The level of $\mathrm{Pb}$ observed in the HNW was above the recommended limit as outlined by WHO, (1999), FAO, (2004) which falls between $0.3 \mathrm{mg} / \mathrm{Kg}$ and $0.01 \mathrm{mg} / \mathrm{Kg}$ in food. When there is exposure to $\mathrm{Pb}$ at high concentrations abnormalities such as lead poisoning occurs and manifestations such as hypertension, renal dysfunction, fatigue, sleeplessness, convulsions, abdominal pain and loss of appetite, headache, numbness, arthritis and hallucination occurs. The concentration of $\mathrm{Pb}$ observed in this study is similar to the result obtained by Farombi et al., (2007) in C. gariepinus from from the Ogun river where they obtained high values of $\mathrm{Pb}$ in the liver and kidney of $C$. gariepinus. The $C d$ concentration observed in this study is consistent and of higher value than that obtained by Farombi et al.(2007) in similar study where values of metal concentration was high in organs of $C$. gariepinus. The mean concentration of metals in all organs was above the permissible levels of food consumption as recommended by the acceptable limit for heavy metals. $\mathrm{Cd}$ is a naturally occurring non- essential trace element and its tendency to bio-accumulate in living organisms often in harzadous levels raises environmental concerns, Authman et al., (2015).The use of $\mathrm{Cd}$ containing fertilizers, agricultural chemicals, pesticides and sewage sludge in farm land could be the possible source of $\mathrm{Cd}$ in the studied water bodies. The concentration level of $\mathrm{Cd}$ in the study is similar to the concentration observed in fish as described by Hashim et al., (2014) from studies conducted at the lower reach of the Kelantan river, Malaysia where the concentrations of $\mathrm{Cd}$ was found to be higher above the critical limit level of the WHO and FAO. The heavy metals concentrations in all the sampling sites showed a higher level in all fish samples even higher than the permissible limit as obtained in the eatable food substances, the level observed showed that they have reached the level of concern. Waakes, (2000) asserted that heavy metals such as Cd 
affects the kidneys and causes symptoms of chronic toxicity, such as impairment of kidney function, poor reproductive capacity, hypertension, tumors and hepatic dysfunction.

The activities of SOD, the redox sensitive thiol compound GSH, CAT and MDA were elevated in all the organs(gills, liver and muscle) The significant increase recorded in these organs would be as a result of the presence of heavy metals in the water, these accumulation of heavy metal might have triggered the production of superoxide anions resulting to the induction of SOD to convert the superoxide radical to $\mathrm{H}_{2} \mathrm{O}_{2}$, SOD catalytically scavenges superoxide radical which appears to be an important agent of oxygen toxicity. GSH showed an elevated level in all the samples and GSH is well understood to be a substrate for the activity of GST. The increase recorded in GSH formation in a high level suggests an adaptation and protective mechanism by this biomolecule against oxidative stress induced by heavy metal and pesticide residues which agrees with the findings of Farombi et al.,(2007).The high level of GSH recorded in the gills could result from the gills being more exposed to contaminated water and as such pollutant(heavy metals) can have access through the fish thin epithelia, this can be attributed to the reasons why there was high level of GSH in the fish .Catalase activity was decreased in the fish specie studied although increase in the activity of CAT and SOD is usually observed in the presence of environmental pollutants as documented by Dautremepitis et al. (2004). The reduced rate of CAT in this study can be attributed to the overshadowing ability of superoxide radicals as asserted by Stanic et al., (2005). Significant elevation of lipid peroxidation in all organs indicate the accumulation of heavy metals in the organs as seen in the data obtained in this results, this elevated concentrations can raise high levels of antioxidants and in some cases cause damages in DNA, proteins and lipids, Pandy et al.,(2003). The presence of antioxidant in fish establishes oxidative stress conditions in fish as a result of the high concentration of heavy metals analyzed in this study.

Chromium is known to be carcinogenic in humans (WHO, 1988). Ahmad et al.,(2006) described the genotoxicity of chromium in the gills and kidneys of Anguilla Anguilla ; while Farag et al., (2006) described DNA damage and high elevation of lipid peroxidation in Chinnook salmon (Oncorhynchus tshawytscha) during chronic exposure to chromium in water; it is on record that cadmium does not generate reactive oxygen species directly but it can alter GSH levels and influence cell thiol status inducing the expression of mettallothioneins in the liver, Sevcikova et al., (2011) .Changes in GSH can lead to lipid peroxidation of cell membranes. In this study the increased level of SOD could result from the high level of mercury present, this agrees with the findings of Monteiro et al.,(2010) who observed high levels of mercury in liver, gills and heart of fresh water Brycon amazonicus. Other metals such as Aluminium detected is a widespread pollutant capable of inducing oxidative stress in fish. This study showed that fish is a strong bioindicator of metals in the environment and can be used as a measure of the pollution level in an environment.

\section{CONCLUSION}

The high level of heavy metals revealed in this study is a reflection of the state of pollution in the HNW. Since aquatic life depends largely on this water for their survival and wellbeing, it is necessary the water bodies in the wetland be monitored by the government in order to regulate and educate people on safety measures when applying some chemicals and to manage waste that makes the presence of heavy metals possible in these water bodies.

\section{REFERENCES}


Achuba, F.I., Ebokaiwe, P., Peretiemo-Clarke. B.O. (2014). Effect of environmental pollution on oxidative stress in African Catfish (Clarias hetrobranchus) International Journal of Environmental Monitoring and Analysis. 2(6):297-301.

Aebi, H. (1974). Catalase in method of enzymatic analysis (Brygmeyer, H.U(ED) Academic press, New York Pp. 673-684

Akinwande, A.A., Abdulkadiri, J.O. and Adesina, B.T. (2016). Oxidative stress and Antioxidant Response in the Giant African Catfish (Heterobranchus Bidorsalis) under Chronic Paraquat Exposure. Nigerian Journal of Fisheries and Aquaculture, 4(2):30-37.

Alksnes, A., and Njaa, R.L. (1981). Catalase, glutathione peroxidase and superoxide dismutase in different fish species. Comp. Biochem, Physiol. 69B: 893-896.

Arimoro, F.O., Chukwuji, M.A.J and Oghenegholome, O. (2000). Effect of industrial waste water on the physical and chemical characteristics of a tropical coastal river. Res. J. Environ. Sci. 2(3):209-220

Beers, R.F. and Sizer, I.W. (1995). A Spectrophotometric method for measuring the breakdown of hydrogen peroxide by catalas. J boil. Chem. 195; 133-104

Cohen, G, Dembrec, D. and Marcus, J. (1970). Measurement of catalase activity in tissue extracts. Analyt. Biochem: 34:30-38

Crapo, J.D., Mc Cord, J.M. and Fridovich, I. (1978). Preparation and assay of superoxide dismutases. Meth. Enzyme 53:328-393.

Dautremepuits, C., Paris-Palacious, S., Betoulle, S., Vernet, G.(2004). Modulation in hepatic and head kidney parameters of crap (Crypinus carpio L.) Induced by copper and chitosan, Comp. Biochem physical. C. Toxicol pharmacol. 137, 325-333.

Egwu, G.N., Okunola, O.J. and Ugwuike, K.C. (2018). Evaluation of some Heavy Metals in Wetland Soils of Uguru Yobe State, Nigeria. Journal of Applied Science Environ .22(6)987-992

Farag, A.M., May, T., Marty, G.D. Easton, M., Harper, D.D., Little, E.E. and Cleveland, L. (2006). Effect of chronic chromium exposure on the health of chronic salmon Oncorhynchus tsharoytscha, Aquatic Toxicolgy 76, 246-257.

Farombi, E.O., Adelowo, O.A. and Ajimoko, Y.R (2007). Biomarkers of oxidative stress and heavy metal levels as indicators of environmental pollution in African catfish larias garieopinus from Nigeria, Ogun river. Int.J.Envirnm. Res. Public Health, 4(2):158-165.

Federal Environmental Protection Agency FEPA. (1991). Natural Environmental protection Effluent Limitation Regulations of 1991 Federal Environmental Protection Agency, Lagos, Nigeria. Ref. S. 1-8

Gutteridge, J.M.C and Wilkins, S. (1982). Copper dependant hydroxyl radical charge to ascorbic acid Fed. European society letters. 137:32

Hunter, F.E; Gebrecki, J.M; Hoffstein, P.E; Weinstein, J. and Scott, A. (1963). Swelling and Lysis of rat liver mitochondria induced by Ferrousion J. Biol. Chem. 238, 847-851

Kaur, M and Jindal, R. (2017). Oxidative stress response in liver, kidney and gills of Ctenopharyngodon idellus (Cuvier and Valenciennes) exposed to chlorpyrifos. Biol med. 2017:1 (4): 103-112.

Kefas, M.; Abubakar, K.A and Ali, J. (2015). The assessment of water Quality via physicochemical parameters and macro invertebrates in Lake Geriyo, yola, Adamawa state, Nigeria. The international Journal of Science and Technology, 3(3). 284290

Misra, H.P. and Fridorch, I., (1972). The role of superoxide ion in the auto-oxidation of epinephrine and a simple assay for superoxide dismutase, J. Bio. Chem. 247:31703175 . 
Mwevura, H; Othman, C; Mhehe, L. (2004). Organochlorine Pesticide Residues in Edible Biota from the coastal area of dar es salaam city, western Indian Ocean J. mar.Sci 1:9196.

Nishida, Y. (2011). The chemical process of oxidative stress by copper (II) and iron (III) ions in several neurodegenerative disorders. Moatshefte for chemie 142, 375-383.

Nwani, C.D., Ekwueme, H.I., Ejere, V.C., Onyeke, C.C., Chukwuka, C.O., Peace, O.N. and Nwadinigwe, A.O. (2015). Physiological effects of paraquat in Juvenile African catfish Clarias griepinus (Burchell, 1822). Journal of Coastal Life Medicine, 3(1):35-43.

Ochuwa, O.G.,Nnamdi, H.A., Emanuel, B., Adebayo, A.O. (2017). Genitoxic, Histopathological and Oxidative Stress Responses in Catfish, Clarias gariepinus, Exposed to two Antifouling points. Journal of health and Pollution, Vol. 7, No. 16 Dec; 2017.

Pandey, S; Parvez, S; sayeed, I; Haque, R; Bin-hafeez, B; Raisuddin, S.(2003). Biomakers of Oxidative stress: A comparative study of river Yamuna Fish Wallago attu (BI \& schnn), Sci Total Environ., 309 105-15.

Sabo, B.B., Ringim, A.S. and Karaye, A.K. (2016). Evaluation of irrigation water trapped by Typha damingensis for heavy metals in Hadejia river, Nigeria. International Journal of Public and Environmental Health. 3(5)107-111

Sevcikova, M., Modra, H., Slaninova, A., Svobodova, Z. (2011). Metals as a cause of oxidative stress in fish: a review. Veterinarni medicina, 56(11):537-546

Tyokumbur, E.T. (2016). Bioaccumulation of heavy metals in organs and tissues of Xenopus laevis and sediment concentrations from Alaro Stream in Ibadan. New York Science journal 9(3): 39

Waakis, M.P. (2000).Cadmium carcinogenesis in review. Journal of inorganic Biochemistry. 79(1) 241-244.

WHO (1988).Environmental health criteria, Chromium, WHO, Genera. 